\title{
Monitored therapy of sporadic mycobacteriosis caused by Mycobacterium genavense in Atlantic canaries (Serinus canaria) and Bengalese finch (Lonchura striata)
}

\author{
Aleksandra Ledwoń ${ }^{\bowtie}$, Izabella Dolka, Krzysztof Adamczyk, Piotr Szeleszczuk \\ Department of Pathology and Veterinary Diagnostics of the Institute of Veterinary Medicine, \\ Warsaw University of Life Sciences, 02-776 Warsaw, Poland \\ aledwonn@yahoo.pl
}

Received: June 4, $2021 \quad$ Accepted: November 25, 2021

\begin{abstract}
Introduction: Mycobacteriosis is a significant disease of companion and wild birds which causes emaciation and widely distributed lesions, as well as being a potential zoonosis. Its primary aetiological agents in birds are Mycobacterium avium subsp. avium and the fastidious Mycobacterium genavense. This study monitored the therapy of birds naturally infected with Mycobacterium genavense to gain understanding of its effectiveness and the interrelation of co-infections with the disease course and pharmacotherapy. Material and Methods: Five Atlantic canaries (Serinus canaria) and one Bengalese finch (Lonchura striata) with tentative diagnoses of mycobacteriosis resulting from $M$. genavense infection were treated twice daily with clarithromycin at $40 \mathrm{mg} / \mathrm{kg}$, ethambutol at $30 \mathrm{mg} / \mathrm{kg}$, and moxifloxacin at $10 \mathrm{mg} / \mathrm{kg}$ for 6 months. Two canaries were also found to be carriers of Cryptosporidium galli. Mycobacteria in faecal samples of all birds were investigated by bacterioscopy and quantitative PCR. Results: Molecular tests yielded positive results for up to four months after treatment initiation for M. genavense and Cryptosporidium, but microscopy failed to detect the latter after four weeks in specimens from one canary. Co-infections with polyomavirus (in all birds) and circovirus and bornavirus (in canaries) were diagnosed. Two birds died during treatment and one was euthanised because of other disease, 1 month after treatment completion. Three canaries were in relatively good health a year after treatment. Conclusion: Canary circovirus and polyomavirus co-infection may suppress the immune system and this may facilitate the development of mycobacteriosis. The set of drugs used led to the complete cure of mycobacteriosis in three canaries. In one bird the disease returned. Clarithromycin was the active drug against $C$. galli. Molecular methods serve well to monitor mycobacteriosis therapy and identify $M$. genavense and C. galli carriage.
\end{abstract}

Keywords: avian mycobacteriosis, canary infectious diseases, Cryptosporidium galli, Mycobacterium genavense, qPCR.

\section{Introduction}

Mycobacteriosis caused by Mycobacterium genavense was diagnosed for the first time in people with HIV (1). Shortly afterwards, it became apparent that this bacterium is the most common cause of mycobacteriosis in pet birds $(11,12,27)$ and those kept in zoological gardens $(24,26)$, although it may also cause disease in other animal species $(14,21,34)$. The bacteria are characterised by very slow growth on selected special media or no growth at all. Therefore, $M$. genavense has been described as a fastidious organism (6), and is a difficult one to culture; PCR tests are the preferred method of diagnosis of this pathogen $(5,17,30,31)$. Since the 1990s, when this bacterium was first detected, there have been numerous reports of its occurrence in Passeriformes, which show that $M$. genavense is a serious problem in those birds kept in captivity $(23,27,30)$. Studies conducted by Schmitz et al. (30) in flocks of pet birds using the qPCR method showed the prevalence of M. genavense in post-mortem studies as ranging from $3 \%$ to $91 \%$, depending on the flock. The faecal-oral route is suspected as the route of infection with M. genavense (19), but the inhalation route cannot be excluded $(22,23)$. An important role in this regard is played by factors promoting the disease, such as immunosuppression caused, inter alia, by viral infections (22, 30, 31). Mycobacteriosis with an $M$. genavense agent is treated in humans, although attempts to treat this disease with the same agent have also been made in companion 
animals (7). Therapy of mycobacteriosis from $M$. genavense infection has not yet been described in birds, but attempts at therapy have been made in birds infected with $M$. avium $(16,18,28)$, and the outcomes of these treatments have not been fully satisfactory; neither have they been completely unsatisfactory. The methods of diagnosis and therapy of mycobacteriosis in humans and animals are constantly being improved. Our study was designed to determine the efficacy of the proposed drug combination in the treatment of mycobacteriosis caused by $M$. genavense, and to assess the suitability of qPCR methods to monitor this therapy.

\section{Material and Methods}

Studied animals. The therapy was implemented in six male birds originating from a place where mycobacterium infection was diagnosed post-mortem in at least two birds. The total breeding stock of Atlantic canary (Serinus canaria) and Bengalese finch (Lonchura striata) during this period was 45 individuals and they were owned by the same breeder. The birds were kept in cages in the breeder's apartment. During the breeding season, adult birds were kept in pairs, while outside the breeding season the males were caged individually, and the females in small groups. Young birds were kept in large cages, several per cage. Some of the adult canaries were also in cages on a sheltered balcony.

Birds were selected for treatment based on the results of a microscopic examination of faeces stained using the Ziehl-Neelsen (ZN) method. In the birds selected, acid-fast bacilli (AFB) were found in at least one sample (Table 1). In canaries 3 and 5, a moderate number of Cryptosporidium cysts were also found in $\mathrm{ZN}$ faecal stain specimens. The owner of the birds agreed to their hospitalisation, treatment and (in fatal outcomes) subsequent post-mortem examinations. The birds were kept in separate cages in the same room during treatment. Thirteen months after treatment completion, canaries 1, 3 and 4 were placed in cages with one-year-old female red-factor canaries naturally infected with canary circovirus $(\mathrm{CaCV})$ and canary polyomavirus $(\mathrm{CaPyV})$ but originating from another flock. The females were kept with the males for four weeks, or for three weeks in the case of canary 4.

Therapy. The therapy was scheduled to last 24 weeks, except in canary 3, which was treated for 29 weeks. The drug combination was administered twice a day for six days a week and once on the other day. It was given to the birds by $0.8 \times 60 \mathrm{~mm}$ feeding tubes into the oesophagus and consisted of clarithromycin (Klacid; Mylan, White Sulphur Springs, WV, USA) at $40 \mathrm{mg} / \mathrm{kg}$ b.w., ethambutol (Ethambutol; Teva, Kraków, Poland) at $30 \mathrm{mg} / \mathrm{kg}$ b.w. and moxifloxacin (Moloxin; Krka, Novo Mesto, Slovenia) at $10 \mathrm{mg} / \mathrm{kg}$ b.w. One day before treatment and weekly thereafter, the body weights of the treated birds were measured, based on which drug dosage was adjusted. Canary 3 was treated again 14 months after completion of the first treatment. The bird received the same drug combination twice a day for seven days a week. The second treatment of this individual was continued until its death on day 87 of treatment.

Humane endpoint. Euthanasia was performed only on birds in a very poor general condition. After prior general anaesthesia with $2 \%$ isoflurane (Aerrane; Baxter, Warsaw, Poland), a pentobarbital sodium solution (Morbital; Biowet, Puławy, Poland) at a dose of $1 \mathrm{~mL} / \mathrm{kg}$ b.w. (10) was administered to the right jugular vein.

Microscopic examination. Microscopic specimens stained using the $\mathrm{ZN}$ method were prepared from the faeces of each bird every day for the first two weeks and once a week thereafter.

Blood sampling. Before and after treatment, blood samples in a volume of 0.1 to $0.2 \mathrm{~mL}$ were taken from the right jugular vein (29) with a tuberculin syringe with a needle of $0.45 \times 13 \mathrm{~mm}$. From these samples, smears coloured using the Hemacolor method (Merck, Darmstadt, Germany) were prepared and used to establish the approximate leukocyte count (Table 3).

Table 1. Description of birds before treatment, clinical signs (if any) and microscopic findings

\begin{tabular}{|c|c|c|c|c|}
\hline Case & $\begin{array}{c}\text { Species/breed/sex/age in } \\
\text { years (y) }\end{array}$ & Clinical signs & $\mathrm{AFB}$ in faeces & $\begin{array}{l}\text { Cryptosporidium } \\
\text { galli in faeces }\end{array}$ \\
\hline 1 & $\begin{array}{l}\text { Canary/lizard/male } \\
4 \mathrm{y}\end{array}$ & Chronic dyspnoea & +++ & - \\
\hline 2 & $\begin{array}{l}\text { Canary/yellow/male } \\
2 \text { y }\end{array}$ & No signs of disease & +++ & - \\
\hline 3 & $\begin{array}{c}\text { Canary/ } \\
\text { Raza Espanola/male } \\
3 \mathrm{y} \\
\end{array}$ & Chronic dyspnoea & $+1-$ & ++ \\
\hline 4 & $\begin{array}{c}\text { Canary/ } \\
\text { Raza Espanola/male } \\
4 \mathrm{y}\end{array}$ & $\begin{array}{l}\text { No rectrices (growth of single deformed } \\
\text { ones, which subsequently fell out) }\end{array}$ & $-/+$ & - \\
\hline 5 & $\begin{array}{c}\text { Canary/ } \\
\text { Raza Espanola/male } \\
2 \text { y }\end{array}$ & No signs of disease & $-1+$ & ++ \\
\hline 6 & $\begin{array}{l}\text { Bengalese finch/ } \\
\text { red-brown/male } \\
2 \mathrm{y} \\
\end{array}$ & No signs of disease & +++ & - \\
\hline
\end{tabular}

$+++-\geq 10 \mathrm{AFB} /$ high-power field (HPF); ++ - 1-10 AFB/HPF; + - 10-99AFB/100 HPF; +/- - 1-9 AFB/100 HPF; - - negative result $(33) ;(-/+)$ - dubious result 
M. genavense quantitative PCR. DNA was extracted from weekly pooled samples of faeces from each bird separately. A GeneMATRIX Stool DNA Purification Kit (EURx, Gdańsk, Poland) was used to extract DNA according to the dedicated protocol. In the second course of treatment conducted in canary 3 only, DNA extraction was performed from faecal samples taken one day before treatment initiation and subsequently 47 times in 87 days of the treatment using a QIAamp DNA Stool Mini Kit (Qiagen, Hilden, Germany), following a two-day protocol (20) including the use of inhibitor-binding tablets (InhibitEX, Qiagen $\mathrm{GmbH}$, Hilden, Germany). Additionally introducing sample homogenisation with glass beads for $10 \mathrm{~min}$ on a GeneReady homogeniser (Hangzhou Lifereal Biotechnology Co., Ltd., Hangzhou, China). DNA extraction from the blood and tissues of the studied birds was performed using the GeneMATRIX Tissue \& Bacterial DNA Purification Kit (EURx).

DNA extracted from faeces was used in two tests: a SYBR Green qPCR (15) and a TaqMan probe qPCR (30). Both tests were conducted on an Mx3005P real-time PCR device (Stratagene, La Jolla, CA, USA). Reactions were analysed with MxPro software (Agilent, Santa Clara, CA, USA). The primers for both tests and the TaqMan probe were designed based on a $M$. genavense hypothetical $21 \mathrm{kDa}$ protein gene (5). Samples taken from canary 3 during the second treatment were only tested with SYBR Green qPCR, which employed the forward primer MG 25-s 5'GAATCCGCTGCTGCTCTG-3' and the reverse primer MG25-as 5'-TCAATGTAGTCCTGTCCGAAC-3' (15) with SG qPCR Master Mix (EURx). The qPCR using the TaqMan probe was performed with the forward primer 5'-AAA CAG CGT CAG GAA ATC-3' and the reverse primer 5'-GTG GGA CGA AGA TGT AGT-3' as well as the TaqMan probe $5^{\prime}$-FAM-AAC CGC TAT CTA CAT CCG CAG-TAMRA-3' (30). The PCR assays were performed with Fast Probe qPCR Master Mix (EURx). In both tests, a result was deemed positive at a cycle threshold of under 35, and for the SYBR Green qPCR test, compliance of the melting curve of the tested samples with the standard was also considered indicative of a positive result. The results of the tests for each bird are shown in Fig. 1 A-D and Fig. 2.

Cryptosporidium spp. nested PCR. Samples of faeces and organs collected from canaries 3 and 5 were used in a nested PCR for cryptosporidium (3) along with the OptiTaq PCR Master Mix (EURx). The reaction conditions followed those described by Camargo et al. (3). Subsequently, the PCR products were sequenced to determine the parasite species.

PCR tests for Mycobacterium spp. and viruses. The samples of DNA extracted from faeces or organs with the highest qPCR result were selected for each canary. These samples were tested using a PCR for Mycobacterium spp. (36), and the PCR products were subsequently sequenced and identified using NCBI BLAST. The DNA isolates were then compared using Genious Prime software (Biomatters, Auckland, New
Zealand). DNA extracted from blood samples and organs (liver, spleen, kidneys, brain, and intestines) was tested in PCRs for circoviruses $(9,32)$ and polyomaviruses (13), but only organs were tested in an RT PCR for avian bornaviruses (15). The PCR products were sequenced, and species were identified.

Necropsy and histopathological examination. A necropsy was performed as soon as possible after a bird's death. Fragments of liver, spleen, kidneys, brain, heart and intestines were fixed in $10 \%$ formalin and examined histopathologically with routine haematoxylin and eosin and $\mathrm{ZN}$ staining.

\section{Results}

Clinical observations and survival during and post treatment. Two birds died during treatment. Canary 5 died just two weeks after treatment initiation, while the Bengalese finch died four months after initiation, after a blood collection procedure. One month after treatment completion, canary 2 was euthanised. Canary 1 was euthanised 15 months after treatment completion. In the same year, canary 4 was taken from its cage by a magpie (Pica pica) and unfortunately a necropsy was not performed. Canary 3 died on day 87 of the second course of treatment. Clinical observations and post-mortem changes in the treated birds are presented in Table 2.

In the female kept with canary 3 , dwelling on the bottom of the cage and lack of reaction to visual stimuli were observed 8 weeks after their separation. This bird was euthanised and necropsied. Histopathological examination of the organs of this female showed, inter alia, mycobacteriosis of the intestines and spleen. The female kept with canary 1 , in which similar clinical signs occurred was also necropsied but no mycobacteriosis was identified. The female kept with canary 4 died two years after their separation; the post-mortem and histopathological examinations showed no mycobacteriosis.

Microscopic examination of faecal samples. Positive microscopy results for mycobacteria were obtained regularly for specimens from canary 1 until the seventh week of treatment, for those from canary 2 until the third week of treatment, and for those from the Bengalese finch in the first week of treatment. In canary 3's specimens, mycobacteria were found sporadically until the fifth week of treatment; in the second course of treatment, mycobacteria were found irregularly until day 20 of treatment. In specimens from canaries 4 and 5, single AFB were found only prior to treatment. Cryptosporidia were found in all faeces specimens: in canary 5 until death and in canary 3 until the fourth week after treatment initiation.

Microscopic examination of blood. All canaries and the Bengalese finch were diagnosed with heteropaenia, lymphocytosis and monocytosis prior to treatment. In all cases except canary 5, moderate leukocytosis was present before treatment initiation. After or during treatment, leukocyte counts decreased in all birds except canary 5 (Table 3 ). 
Table 2. Results of clinical, post-mortem and histopathological examinations, and PCR tests of organ tissues for M. genavense

\begin{tabular}{|c|c|c|c|c|c|}
\hline Case & $\begin{array}{l}\text { Clinical observations during } \\
\text { treatment }\end{array}$ & $\begin{array}{l}\text { Observations after } \\
\text { treatment }\end{array}$ & Necropsy findings & Histopathology & $\begin{array}{l}\text { Results of } \\
\text { organ } \\
\text { qPCR for } \\
\text { M. } \\
\text { genavense }\end{array}$ \\
\hline 1 & $\begin{array}{l}\text { After three weeks of } \\
\text { treatment, cessation of } \\
\text { crepitant rale at rest, } \\
\text { occurrence of vocalisations; } \\
\text { after two months, cessation } \\
\text { of signs of stress-induced } \\
\text { dyspnoea. } \\
\text { During treatment, two } \\
\text { periods of watery diarrhoea: } \\
\text { at the beginning } \\
\text { of treatment and one month } \\
\text { after treatment initiation. } \\
\text { Bird showing susceptibility } \\
\text { to stress. }\end{array}$ & $\begin{array}{l}\text { Thirteen months } \\
\text { after treatment } \\
\text { completion, placed } \\
\text { in a cage with } \\
\text { a female, which laid } \\
\text { normal eggs. } \\
\text { Fifteen months after } \\
\text { treatment } \\
\text { completion, } \\
\text { dwelling on the } \\
\text { bottom of the cage, } \\
\text { hypothermia, } \\
\text { polyuria, } \\
\text { polydypsia, } \\
\text { anorexia. }\end{array}$ & $\begin{array}{l}\text { Moderate liver } \\
\text { enlargement and } \\
\text { yellowing, grey foci up } \\
\text { to } 1 \mathrm{~mm} \text { on the liver } \\
\text { surface, } \\
\text { cholecystolithiasis, } \\
\text { renal oedema, right } \\
\text { ventricle dilation, } \\
\text { inactive testes. }\end{array}$ & $\begin{array}{l}\text { Lymphoplasmacytic periportal } \\
\text { hepatitis with proliferating bile } \\
\text { ductules, cholestasis; chronic } \\
\text { enteritis; } \\
\text { focal myocarditis and fibrosis; } \\
\text { membranoproliferative } \\
\text { glomerulopathy, bile droplets in } \\
\text { tubular epithelial cells; } \\
\text { splenic lymphoid depletion; } \\
\text { neuronal damage and gliosis. } \\
\text { ZN-negative }\end{array}$ & Negative \\
\hline 2 & $\begin{array}{l}\text { One month before treatment } \\
\text { completion, neurological } \\
\text { signs occurred. The signs } \\
\text { receded following } \\
\text { supportive treatment. }\end{array}$ & $\begin{array}{l}\text { One month after } \\
\text { treatment } \\
\text { completion, after } 10 \\
\text { days of supportive } \\
\text { treatment, } \\
\text { neurological signs } \\
\text { returned. The } \\
\text { canary was } \\
\text { euthanised. }\end{array}$ & $\begin{array}{l}\text { Moderately good } \\
\text { nutrition status, loss of } \\
\text { forebrain and } \\
\text { hydrocephalus, liver } \\
\text { yellowing and slight } \\
\text { enlargement, slight } \\
\text { kidney and spleen } \\
\text { oedema, inactive testes. }\end{array}$ & $\begin{array}{l}\text { Hepatic lipidosis; chronic enteritis; } \\
\text { fat droplets in renal epithelial cells; } \\
\text { splenic lymphoid depletion; } \\
\text { neuronal damage, gliosis, focal } \\
\text { vacuolation of neuropil and } \\
\text { oedema. } \\
\text { ZN-negative }\end{array}$ & Negative \\
\hline 3 & $\begin{array}{l}\text { Complete cessation of } \\
\text { dyspnoea after } 26 \text { days of } \\
\text { treatment. }\end{array}$ & $\begin{array}{l}\text { Prolonged periods } \\
\text { of moulting. } \\
\text { Periodic post- } \\
\text { exercise dyspnoea. } \\
\text { Fourteen months } \\
\text { after treatment, } \\
\text { moderately } \\
\text { numerous AFB in } \\
\text { faeces, significant } \\
\text { liver enlargement. }\end{array}$ & $\begin{array}{l}\text { Moderately good } \\
\text { nutrition status, } \\
\text { significant hepato- and } \\
\text { splenomegaly, paleness } \\
\text { of the liver and spleen, } \\
\text { inactive testes. }\end{array}$ & $\begin{array}{l}\text { Multifocal to coalescing hepatic } \\
\text { granulomas; } \\
\text { intestinal crypt loss, fibrosis of the } \\
\text { lamina propria, and focal } \\
\text { granulomatous enteritis; } \\
\text { mesangioproliferative } \\
\text { glomerulopathy, necrotic tubular } \\
\text { epithelial cells, lymphoid follicle } \\
\text { formation in the interstitial tissue; } \\
\text { splenic coalescing granulomas; } \\
\text { a few mononuclear cells aggregated } \\
\text { closely to the leptomeninges, } \\
\text { gliosis and neuronal damage. } \\
\text { ZN-positive (liver, pancreas, } \\
\text { intestine, kidney, spleen and lungs). }\end{array}$ & Positive \\
\hline 4 & $\begin{array}{l}\text { Good health throughout the } \\
\text { treatment period. }\end{array}$ & $\begin{array}{l}\text { Prolonged periods } \\
\text { of moulting. }\end{array}$ & Not tested & Not tested & Not tested \\
\hline 5 & $\begin{array}{l}\text { Found dead after two weeks } \\
\text { of treatment. }\end{array}$ & $\mathrm{N} / \mathrm{a}$ & $\mathrm{N} / \mathrm{a}$ & $\begin{array}{l}\text { Fungal pneumonia; } \\
\text { neuronal damage and gliosis. } \\
\text { A mistake in the procedure of } \\
\text { fixing the remaining tissues } \\
\text { prevented their histopathological } \\
\text { evaluation. } \\
\text { ZN-positive (liver, spleen and lungs } \\
\text { in cytology). }\end{array}$ & Positive \\
\hline 6 & $\begin{array}{l}\text { Good condition throughout } \\
\text { the treatment period with } \\
\text { beak hyperplasia requiring } \\
\text { correction. Four months } \\
\text { after treatment initiation, the } \\
\text { bird died owing to } \\
\text { haemorrhage after blood } \\
\text { sampling from the external } \\
\text { jugular vein. }\end{array}$ & - & $\begin{array}{l}\text { Good nutrition status } \\
\text { and musculature, } \\
\text { moderate spleen } \\
\text { enlargement, active } \\
\text { testes. }\end{array}$ & $\begin{array}{l}\text { Hepatic lipidosis, proliferation of } \\
\text { bile ducts, cholestasis fibrinoid } \\
\text { necrosis of vascular walls; chronic } \\
\text { enteritis; } \\
\text { splenic lymphoid depletion, } \\
\text { vascular fibrinoid necrosis; } \\
\text { membranoproliferative } \\
\text { glomerulopathy, } \\
\text { bile droplets in tubular epithelial } \\
\text { cells; } \\
\text { neuronal damage and gliosis. } \\
\text { ZN negative }\end{array}$ & Positive \\
\hline
\end{tabular}

ZN - Ziehl-Neelsen staining; N/a - not applicable 


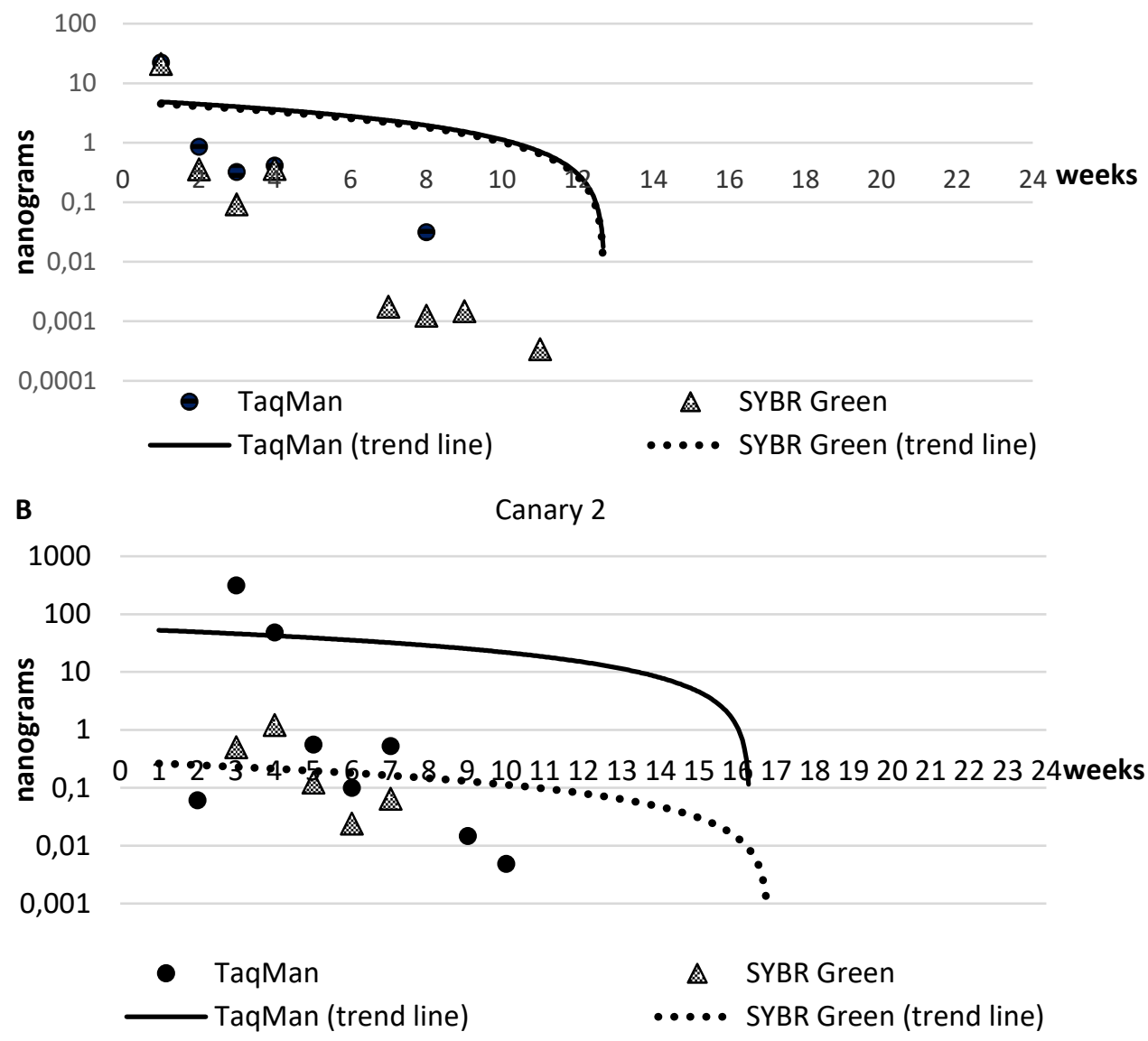

C

Canary $3-1^{\text {st }}$ treatment

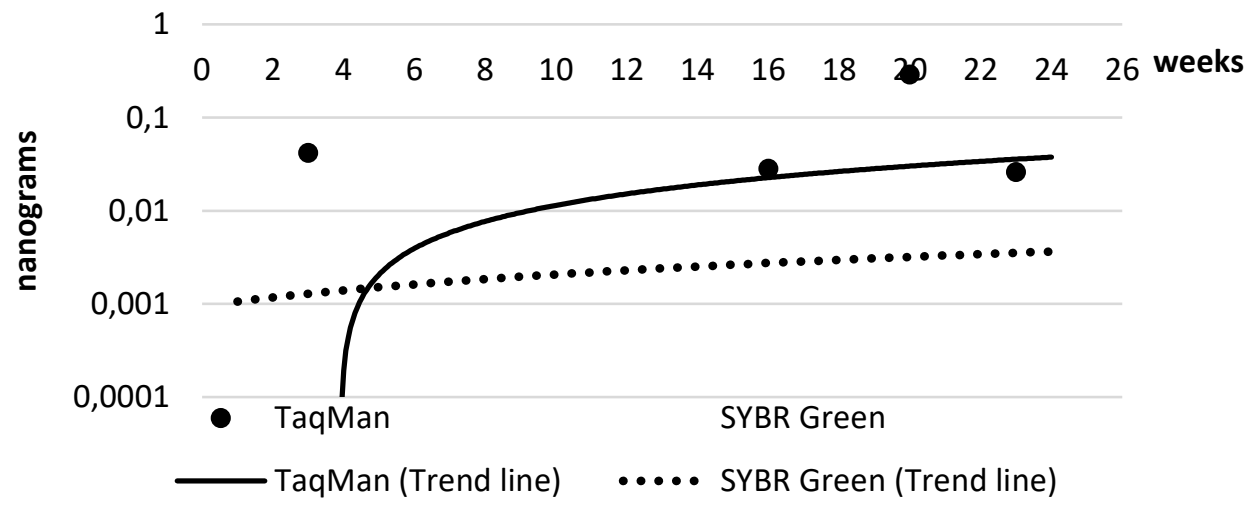

D Bengalese finch

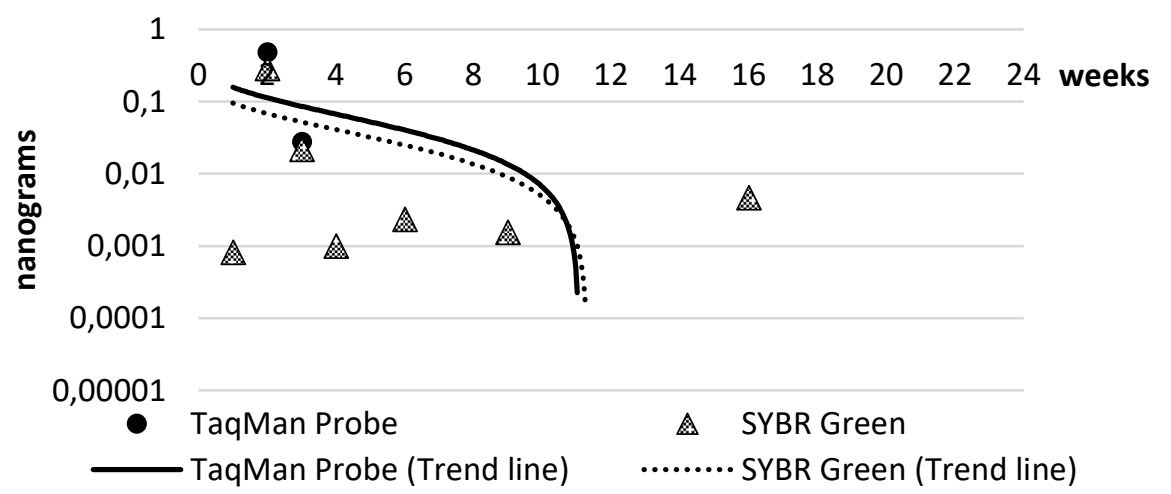

Fig. 1. Comparison of results of SG qPCR and TaqMan qPCR tests to detect $M$. genavense 
Table 3. Comparison of pre-treatment and post-treatment blood counts

\begin{tabular}{|c|c|c|c|c|c|c|c|}
\hline & \multicolumn{7}{|c|}{ Leukocyte parameters } \\
\hline & $\begin{array}{c}\text { BT - before } \\
\text { treatment, AT - } \\
\text { after treatment }\end{array}$ & $\begin{array}{l}\text { WBC } \\
(\mathrm{g} / \mathrm{L})\end{array}$ & $\begin{array}{l}\text { Heterophils } \\
(\%)\end{array}$ & $\begin{array}{l}\text { Lymphocytes } \\
(\%)\end{array}$ & $\begin{array}{c}\text { Monocytes } \\
(\%)\end{array}$ & $\begin{array}{c}\text { Eosinophils } \\
(\%)\end{array}$ & $\begin{array}{c}\text { Basophils } \\
(\%)\end{array}$ \\
\hline $\begin{array}{c}\text { Canary reference } \\
\text { values (13) }\end{array}$ & & $4-9$ & $50-80$ & $20-45$ & $0-1$ & $0-2$ & $0-1$ \\
\hline \multirow{2}{*}{ Case 1} & BT & 15.2 & 26 & 57 & 17 & 0 & 0 \\
\hline & $\mathrm{AT}$ & 10.8 & 26 & 64 & 12 & 0 & 0 \\
\hline \multirow{2}{*}{ Case 2} & $\mathrm{BT}$ & 23 & 32 & 51 & 17 & 0 & 0 \\
\hline & AT & 16.32 & 16 & 75 & 16 & 0 & 0 \\
\hline \multirow{2}{*}{ Case 3} & BT & 10.28 & 18 & 71 & 11 & 0 & 0 \\
\hline & AT & 7.4 & 5 & 88 & 11 & 0 & 0 \\
\hline \multirow{2}{*}{ Case 4} & $\mathrm{BT}$ & 13.75 & 6 & 87 & 7 & 0 & 0 \\
\hline & AT & 8.32 & 8 & 89 & 5 & 0 & 0 \\
\hline Case 5 & $\mathrm{BT}$ & 7 & 25 & 60 & 13 & 2 & 0 \\
\hline $\begin{array}{c}\text { Finch reference } \\
\text { values (13) }\end{array}$ & & $3-8$ & $20-65$ & $20-65$ & $0-1$ & $0-1$ & $0-5$ \\
\hline \multirow{2}{*}{ Case 6} & BT & 10.28 & 18 & 71 & 11 & 0 & 0 \\
\hline & AT & 7.14 & 56 & 37 & 5 & 0 & 2 \\
\hline
\end{tabular}

Canary $3-2^{\text {nd }}$ treatment

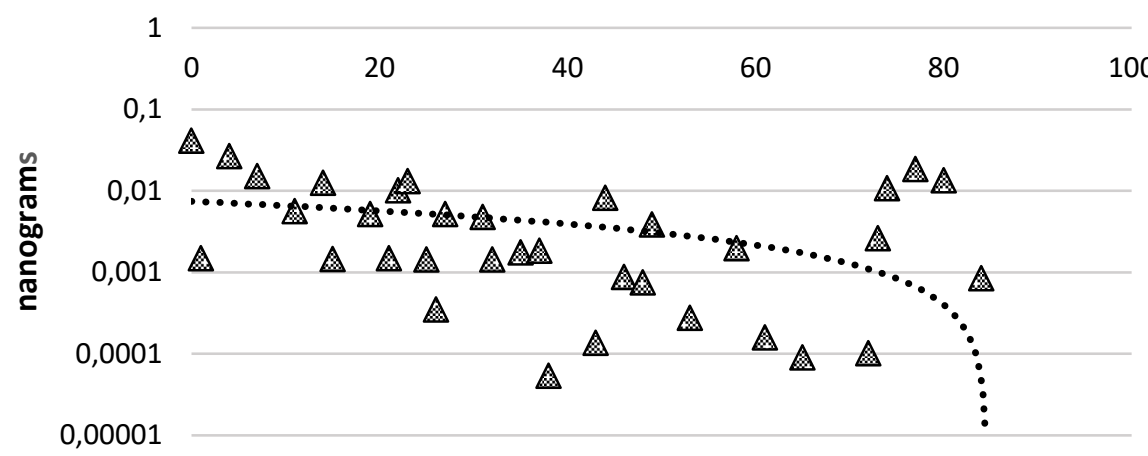

$\Delta \quad$ SYBR Green $\quad$....... SYBR Green (trend line)

Fig. 2. Positive SG qPCR results during the second treatment of canary 3

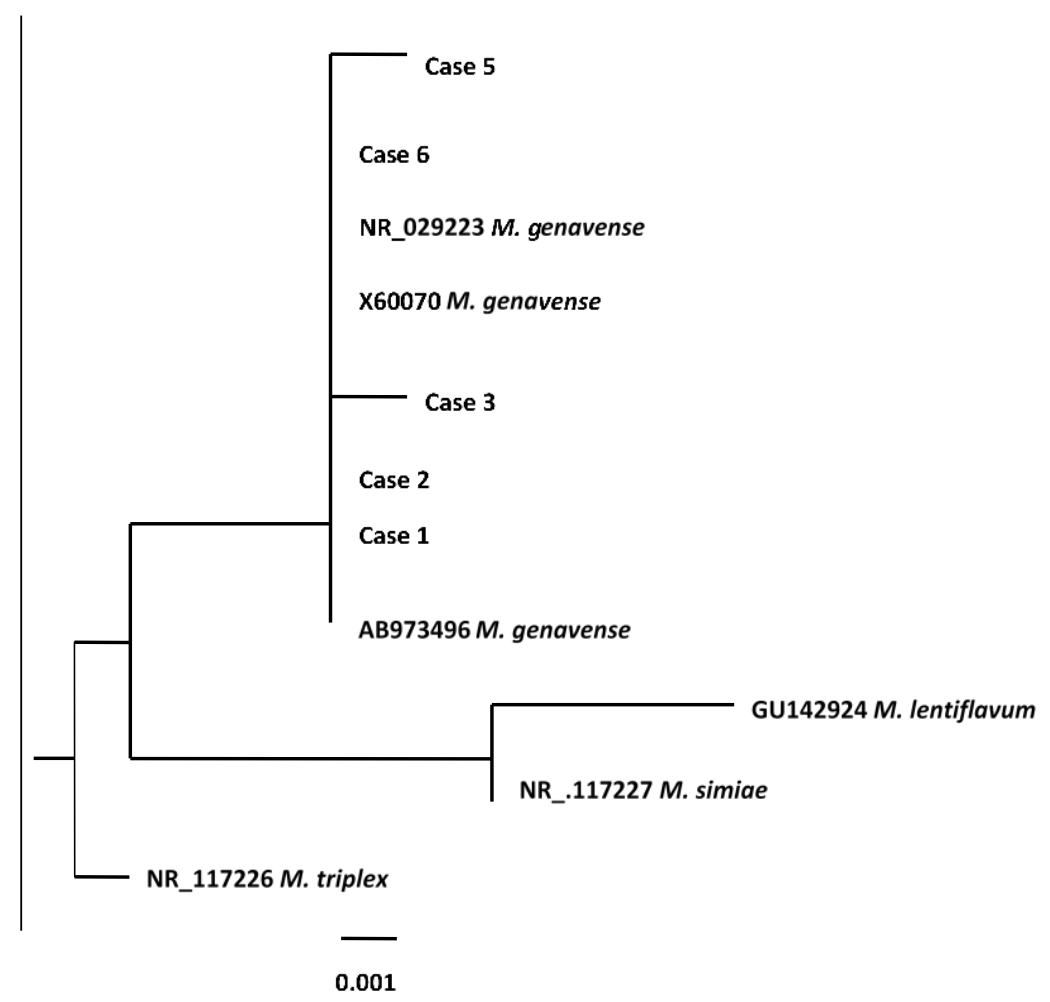

Fig. 3. Phylogenetic tree based on the $16 \mathrm{~S}$ rRNA gene, including Mycobacterium strains derived from treated canaries (cases: 1, 2, 3, 5 and 6) and other avian strains selected from the GenBank NCBI database. The tree was constructed by a neighbour-joining algorithm. The bar indicates $0.001 \mathrm{bp}$ sequence divergence 
Quantitative PCR. For canary 1, 17 positive SG qPCR results and 8 positive TaqMan qPCR results were obtained (Fig. 1A). The SG qPCR yielded four and TaqMan qPCR yielded eight positive results for canary 2 (Fig. 1B). For canary 3, two and four positive results were obtained in SG and TaqMan, respectively (Fig. 1C). Only two positive SG qPCR results were obtained from the tested material of canary 4 , in the eighth and fourteenth weeks. No positive results were obtained for faeces in either test on canary 5's specimens. In the Bengalese finch, seven positive SG qPCR and two positive TaqMan qPCR results were obtained (Fig. 1D). The second test conducted on canary 3's specimens gave 34 positive results out of 48 tested samples (Fig. 2).

Other PCR tests. PCR products of $1,030 \mathrm{bp}$ in size (34) from samples taken from canaries 1, 2, 3 (before the first and second treatments), 5 and 6 were sequenced. No sequenceable product was obtained from canary 4 in this reaction. All isolates were identified as $M$. genavense and are presented on a phylogenetic tree (Fig. 3).

In samples of faeces-isolated DNA from canary 3, the presence of cryptosporidia was revealed up to the $17^{\text {th }}$ week after treatment initiation; in canary 5 , this presence was found in all faeces and intestine samples. Based on the sequencing, the samples were identified as Cryptosporidium galli.

All blood and organ samples revealed the DNA of canary circovirus and polyomavirus. In canaries 1, 2, 3 and all red-factor females, bornavirus was detected in the tested organs (liver, spleen, kidneys, brain, and intestines). Infection with bornavirus was also found in several other canaries from the same breeder who submitted the five treated males, while no bornavirus infection was found in the other tested canaries from the breeder of red-factor females. In the Bengalese finch, the DNA of finch polyomavirus (FPyV) was found in blood and organs.

\section{Discussion}

Canaries and Bengalese finches are good candidates for the proposed treatment. Direct oral administration allows accurate and regular dosing but is feasible only in individual diseased birds housed in small hospital cages (29). An alternative, less stressful method of treatment is to administer drugs with drinking water, but this method does not ensure the correct dosage of the drug (29), especially when it is poorly soluble in water. The authors' experience shows that canaries and Bengalese finches get used to drug administration through an oesophageal tube as the therapy continues, and immediately after being released from the hand, they return to normal activity.

The basis for the selection of drugs and their dosage were previously conducted studies on the effectiveness of the treatment of mycobacteriosis in budgerigars (Melopsittacus undulatus) (16). The present study demonstrated limited efficacy of therapy of $M$. genavense infection using the described method. Similar effects were achieved in the previously referenced attempt to treat $M$. avium in budgerigars (16) and another to treat the infection in Barbary doves (Streptopelia risoria) (28). One of the canaries in the present research was not cured despite 29 weeks of treatment. One year following the treatment, that canary infected a female kept in the same cage for one month. The literature describes a relapse of an apparently cured ferret when mycobacteriosis recurred following a 6-month course of treatment (7). Two birds which shed significant numbers of mycobacteria in their faeces before treatment were cured of mycobacteriosis but developed other fatal diseases. Similar cases have also been described in ferrets treated for mycobacteriosis caused by $M$. genavense (21). In three birds, we failed to establish the efficacy of therapy because of the death of one before treatment completion and the impossibility of performing a necropsy other. Retreatment of canary 3 did not stop the disease, although its apparent efficacy could be assumed based on the decrease to zero presence of acid-fast bacteria in faeces.

Quantitative PCR tests are a useful tool for monitoring the therapy of $M$. genavense-induced mycobacteriosis in birds. The assessment of the two PCR methods used allows us to conclude that the TaqMan probe (31) produces more specific results, because the SYBR Green method (17) required result selection based on the melting curve. The TaqMan method was also less time-consuming. However, more positive results were obtained in the qPCR employing SYBR Green. The superiority of the results obtained for samples taken from canary 3 during the second treatment can be explained by the longer sample incubation time as well as the use of inhibitor-binding tablets. Emulsification with glass beads was used in both methods.

Mycobacteriosis in the examined canaries may have been promoted by immunosuppression caused by the concurrent $\mathrm{CaCV}$ and $\mathrm{CaPyV}$ infections, as it also may have been by FPyV infection in the Bengalese finch. In a retrospective study conducted by Schmitz et al. (31) in birds with mycobacteriosis caused by $M$. genavense detected post mortem, polyomavirus infection was revealed in $25 \%$ and circovirus infection in $35 \%$ of cases. However, the birds most susceptible to mycobacteriosis were those infected with both of these viruses. Due to the concurrent $\mathrm{CaCV}$ and $\mathrm{CaPyV}$ infections in canary 4 , it is difficult to determine which virus had a greater effect on the loss of feathers on the tail. Schmitz et al. (31) suggested a significant effect of polyomavirus on moulting in birds. Typical changes in the blood counts associated with mycobacteriosis are leukocytosis, significant heterophilia and monocytosis (25). Leukocytosis was found in the described cases; however, it decreased significantly most probably as a result of the therapy. Monocytosis and moderate leukocytosis, as well as heteropaenia with lymphocytosis instead of heterophilia were also evident in the examined 
birds. This heteropaenia may have been caused by the co-existing viral infections (35). The treatment used was efficacious against Cryptosporidium galli, but negative PCR results were first obtained only after as long as 17 weeks. Of the drugs in the combination used, clarithromycin was active against Cryptosporidium (8). While mycobacteriosis therapy in birds continues to be controversial (2), studies such as this can help veterinarians in deciding between treatment and euthanasia of infected birds. Euthanasia still tends to be preferred because of the long duration and poor efficacy of therapy, as well as the real risk that mycobacteria pose to human health. Finally, it is worth emphasising that before making a decision on treatment, it is constructive to investigate whether the birds have any coexisting viral infections such as bornavirus which usually develop into fatal disease. The authors are aware that the number of birds used in this study was too small for it to be regarded as rigorous, but even so, it can be concluded that the molecular methods used in the study, which are significantly more sensitive than bacterioscopy and culturing, can be used not only to monitor mycobacteriosis therapy, but also to identify M. genavense and C. galli carriers in pet bird flocks.

Conflict of Interests Statement. The authors declare that there is no conflict of interests regarding the publication of this article.

Financial Disclosure Statement. This study was supported by Warsaw University of Life Sciences.

Animal Rights Statement. Naturally infected birds were treated. Their owner consented to the diagnostic procedures, treatment, euthanasia and necropsy of these birds.

\section{References}

1. Böttger E.C., Teske A., Kirschner P., Bost S., Chang H.R., Beer V., Hirschel B.: Disseminated "Mycobacterium genavense" infection in patients with AIDS. Lancet 1992, 340, 76-80, doi: 10.1016/0140-6736(92)90397-L.

2. Buur J., Saggese M.D.: Taking a rational approach in the treatment of avian mycobacteriosis. Vet Clin Exot Anim Pract 2012, 15, 57-70, doi: 10.1016/j.cvex.2011.12.001.

3. Camargo V.D.S., Santana B.N., Ferrari E.D., Nakamura A.A., Nagata W.B., Nardi A.R.M., Meireles M.V.: Detection and molecular characterization of Cryptosporidium spp. in captive canaries (Serinus canaria) using different diagnostic methods. Rev Bras Parasitol Vet 2018, 27, 61-66, doi: 10.1590/S1984296120180010.

4. Cattarossi D., Azzara E., Catania S.: Clinical and laboratory practice for canaries and true finches. Vet Clin Exot Anim Pract 2013, 16, 31-46, doi: 10.1016/j.cvex.2012.09.002.

5. Chevrier D., Oprisan G., Maresca A., Matsiota-Bernard P., Guesdon J.L.: Isolation of a specific DNA fragment and development of a PCR-based method for the detection of Mycobacterium genavense. FEMS Immunol Med Microbiol 1999, 23, 243-252, doi: 10.1016/S0928-8244(98)00143-6.

6. Coyle M.B. Carlson L.C., Wallis C.K., Leonard R.B., Raisys V.A., Kilburn J.O., Samadpour M., Böttger E.C.:
Laboratory aspects of "Mycobacterium genavense," a proposed species isolated from AIDS patients. J Clin Microbiol 1992, 30, 3206-3212, doi: 10.1128/jcm.30.12.3206-3212.1992.

7. De Lorenzi G., Kamphuisen K., Biscontini G., Pacciarini M., Zanoni M., Luppi A.: Mycobacterium genavense Infection in a Domestic Ferret (Mustela putorius furo). Top Companion Anim Med 2018, 33, 119-121, doi: 10.1053/j.tcam.2018.10.001.

8. Fujikawa H., Miyakawa H., Iguchi K., Nishizawa M., Moro K., Nagai K., Ishibashi M.: Intestinal cryptosporidiosis as an initial manifestation in a previously healthy Japanese patient with AIDS. J Gastroenterol 2002, 37, 840-843, doi: 10.1007/s005350200138.

9. Halami M.Y., Nieper H., Müller H., Johne R.: Detection of a novel circovirus in mute swans (Cygnus olor) by using nested broadspectrum PCR. Virus Res 2008, 132, 208-212, doi: 10.1016/j.virusres.2007.11.001

10. Hawkins M.G., Barron H.W., Speer B.L., Pollock C., Carpenter J.W.: Chapter 5: Birds. In: Exotic Animal Formulary, fourth edition, edited by J.W. Carpenter, W.B. Saunders, Philadelphia, 2013, pp. $183-454$

11. Hoop R.K., Böttger E.C., Ossent P., Salfinger M.: Mycobacteriosis due to Mycobacterium genavense in six pet birds. J Clin Microbiol 1993, 31, 990-993, doi: 10.1128/jcm.31.4.990993.1993.

12. Hoop R.K., Böttger E.C., Pfyffer G.E.: Etiological agents of mycobacterioses in pet birds between 1986 and 1995. J Clin Microbiol 1996, 34, 991-992, doi: 10.1128/jcm.34.4.991992.1996.

13. Johne R., Enderlein D., Nieper H., Müller H.: Novel Polyomavirus Detected in the Feces of a Chimpanzee by Nested Broad-Spectrum PCR. J Virol 2005, 79, 3883-3887, doi: 10.1128/JVI.79.6.38833887.2005.

14. Kiehn T.E., Hoefer H., Bottger E.C., Ross R., Wong M., Edwards F., Antinoff N., Armstrong D.: Mycobacterium genavense infections in pet animals. J Clin Microbiol 1996, 34, 1840-1842.

15. Kistler A.L., Gancz A., Clubb S., Skewes-Cox P., Fischer K., Sorber K., Chiu C.Y., Lublin A., Mechani S., Farnoushi Y., Greninger A., Wen C.C., Karlene S.B., Ganem D., DeRisi J.L.: Recovery of divergent avian bornaviruses from cases of proventricular dilatation disease: identification of a candidate etiologic agent. Virol J 2008, 5, 88, doi: 10.1186/1743-422X-5-88.

16. Ledwoń A., Dolka I., Dolka B., Cegiełkowska M., Czopowicz M., Szeleszczuk P.: Multidrug therapy of Mycobacterium avium subsp. avium infection in experimentally inoculated budgerigars (Melopsittacus undulatus). Avian Pathol 2015, 44, 470-474, doi: 10.1080/03079457.2015.1086973.

17. Ledwoń A., Szeleszczuk P., Malicka E., Dolka I., Zwolska Z., Augustynowicz-Kopeć E., Zabost A.: Mycobacteriosis caused by Mycobacterium genavense in lineolated parakeet (Bolborhynchus lineola). A case report. Bull Vet Inst Pulawy 2009, 53, 209-212.

18. Ledwoń A., Szeleszczuk P., Miąsko M., Napiórkowska A., Augustynowicz-Kopeć E., Parniewski P., Majchrzak M., Czopowicz M., Adamczyk K., Bonecka J.: Case study and attempt of treatment of mycobacteriosis caused by Mycobacterium avium in a parental flock of meat-breed pigeons. Avian Dis 2020, 64, 335-342, doi: 10.1637/aviandiseases-D-19-00148.

19. Lennox A.M.: Mycobacteriosis in companion psittacine birds: a review. J Avian Med Surg 2007, 21, 181-187, doi: 10.1647/1082-6742(2007)21[181:MICPBA]2.0.CO;2.

20. Loss Chaves S., Dias I., Pomilla C.: Extraction of genomic DNA from carnivore faecal samples using QIAamp DNA Stool Mini Kit. (Modified from QIAamp® DNA Stool Handbook) Stool Extraction Protocol, 2010.

21. Lucas J., Lucas A., Furber H., James G., Hughes M.S., Martin P., Chen S.C., Mitchell D.H., Love D.N., Malik R.: Mycobacterium genavense infection in two aged ferrets with conjunctival lesions. Aust Vet J 2000, 78, 685-689, doi: 10.1111/j.17510813.2000.tb10406.x.

22. Manarolla G., Liandris E., Pisoni G., Moroni P., Piccinini R., Rampin T.: Mycobacterium genavense and avian polyomavirus co-infection in a European goldfinch (Carduelis carduelis). Avian Pathol 2007, 36, 423-426, doi: 10.1080/03079450701598390. 
23. Manarolla G., Liandris E., Pisoni G., Sassera D., Grilli G., Gallazzi D., Sironi G., Moroni P., Piccinini R., Rampin T.: Avian mycobacteriosis in companion birds: 20-year survey. Vet Microbiol 2009, 133, 323-327, doi: 10.1016/j.vetmic. 2008.07.017.

24. Pfeiffer W., Braun J., Burchell J., Witte C.L., Rideout B.A.: Whole-genome analysis of mycobacteria from birds at the San Diego Zoo. PLoS One 2017, 12:e0173464, doi: 10.1371/journal.pone. 0173464.

25. Pollock C.G.: Chapter 14: Implications of mycobacteria in clinical disorders. In: Clinical Avian Medicine Vol II, edited by G.J. Harrison, T.L. Lightfoot, Spix Publishing, Palm Beach, FL, 2006, pp. 681-690.

26. Portaels F., Realini L., Bauwens L., Hirschel B., Meyers W.M., de Meurichy W.: Mycobacteriosis caused by Mycobacterium genavense in birds kept in a zoo: 11-year survey. J Clin Microbiol 1996, 34, 319-323, doi: 10.1128/jcm.34.2.319-323.1996.

27. Ramis A., Ferrer L., Aranaz A., Liébana E., Mateos A., Domínguez L., Pascual C., Fdez-Garayazabal J., Collins M.D.: Mycobacterium genavense infection in canaries. Avian Dis 1996, 40, 246-251, doi: 10.2307/1592398.

28. Saggese M.D., Tizard I., Gray P., Phalen D.N.: Evaluation of multidrug therapy with azithromycin, rifampin, and ethambutol for the treatment of Mycobacterium avium subsp avium in ringneck doves (Streptopelia risoria): An uncontrolled clinical study. J Avian Med Surg 2014, 28, 280-289, doi: 10.1647/2012-067R1.

29. Sandmeier P., Coutteel P.: Chapter 25: Management of canaries, finches and mynahs. In: Clinical Avian Medicine Vol II, edited by
G.J. Harrison, T.L. Lightfoot, Spix Publishing, Palm Beach, FL, 2006, pp. 879-913.

30. Schmitz A., Korbel R., Thiel S., Wörle B., Gohl C., Rinder M.: High prevalence of Mycobacterium genavense within flocks of pet birds. Vet Microbiol 2018, 218, 40-44, doi: 10.1016/j.vetmic. 2018.03.026

31. Schmitz A., Rinder M., Thiel S., Peschel A., Moser K., Reese S., Korbel R.: Retrospective evaluation of clinical signs and gross pathologic findings in birds infected with Mycobacterium genavense. J Avian Med Surg 2018, 32, 194-204, doi: 10.1647/2017-261.

32. Sheykhi A., Sheikhi N., Charkhkar S., Brujeni G.N.: Detection and characterization of circovirus in canary flocks. Avian Dis 2018, 62, 137-142, doi: 10.1637/11776-120417-RegR.

33. Stop TB Partnership: Laboratory Diagnosis of Tuberculosis by Sputum Microscopy. 2013, 71-72.

34. Ullmann L.S., das Neves Dias-Neto R., Cagnini D.Q., Yamatogi R.S., Oliveira-Filho J.P., Nemer V., Teixeira R.H.F., Biondo A.W., Araújo J.P. Jr.: Mycobacterium genavense infection in two species of captive snakes. J Venom Anim Toxins Incl Trop Dis 2016, 22, 27, doi: 10.1186/s40409-016-0082-7.

35. Webb J.L., Latimer K.S.: Chapter 2: Leukocytes. In: Duncan and Prasse's Veterinary Laboratory Medicine: Clinical Pathology, fifth edition, edited by K.S. Latimer, Wiley-Blackwell, Ames, 2011, pp. 45-81.

36. Wilton S., Cousins D.: Detection and identification of multiple mycobacterial pathogens by DNA amplification in a single tube. PCR Methods Appl 1992, 1, 269-273, doi: 10.1101/gr.1.4.269. 